\title{
Inheritance of Tomato Necrotic Ring Virus Resistance in Capsicum annuum
}

\author{
Pailin Puangmalai ${ }^{1,2}$, Nuttha Potapohn ${ }^{1}$, Angsana Akarapisarn ${ }^{1} \&$ Henk Jan Pascha ${ }^{2}$ \\ ${ }^{1}$ Faculty of Agriculture, Chiang Mai University, Chiang Mai, Thailand \\ ${ }^{2}$ Hortigenetics Research, East West Seed Company, Chiang Mai, Thailand \\ Correspondence: Pailin Puangmalai, Faculty of Agriculture, Chiang Mai University, Chiang Mai, Thailand. \\ E-mail: Pailin.noi@gmail.com \\ Pailin Puangmalai, Hortigenetics Research, East West Seed Company, Chiang Mai, Thailand. E-mail: \\ pailin.puangmalai@eastwestseed.com
}

Received: November 11, 2012 Accepted: November 29, 2012 Online Published: January 15, 2013

doi:10.5539/jas.v5n2p129 URL: http://dx.doi.org/10.5539/jas.v5n2p129

\begin{abstract}
Tomato necrotic ring virus (TNRV) is a newly identified species of tospovirus in Thailand. The virus is widely spread and causes severe yield losses of vegetable crops such as tomato and pepper. Chemical control of the vector, thrips species, is very difficult, and the introduction of virus resistance would be a better approach to manage the disease.. In a previous study, two related Capsicum annuum lines, PY-6423 and PY-6424, were identified, which conferred medium resistance to TNRV. These two resistant lines were employed in an inheritance study in order to determine the number of genes controlling resistance in $C$. annuum. Therefore, the susceptible parent Early California wonder (ECW) was crossed with the resistant lines and F1 progenies were backcrossed to the susceptible and resistant parents as well as $\mathrm{F} 2$ were made. Evaluation of the $\mathrm{F} 1, \mathrm{~F} 2$ and $\mathrm{BC}_{\mathrm{S}}$ and $\mathrm{BC}_{\mathrm{R}}$ indicated that the inheritance of the resistance fits a single recessive gene model.
\end{abstract}

Keywords: Capsicum annuum, Tospovirus, Tomato necrotic ring virus, Inheritance, Resistance

\section{Introduction}

Tospoviruses which are transmitted by thrips, cause significant losses in yield and quality of vegetables, legumes and ornamental crops in many parts of the world (Mumford et al., 1996; Pappu et al., 2009). Capsicum annuum is a very popular crop in Thailand, of which the production has been declining lately due to tospoviruses in both open field and greenhouse production. Plants are highly susceptible to these viruses at all stages of development, showing severe symptoms, usually necrotic ringspots, on leaves stem and fruits (Chiemsombat et al., 2010). Most of the seeds of blocky sweet pepper varieties grown in Thailand are imported from European seed companies and these varieties are very susceptible to tospoviruses. In 2008, tomato plants showing distinct yellowing and necrotic rings on leaves and fruits resembling to tospovirus symptoms were observed in a greenhouse in Chiang Mai. Samples from infested tomato and bell pepper plants were collected and identified as tospovirus. The result revealed a new tospovirus species named Tomato necrotic ring virus (TNRV) (Hassani-Mehraban et al., 2011). The virus infesting the tomatoes and peppers in Chiang Mai was the same species as found in other parts of the country. Up to date, the genus Tospovirus comprises at least 20 assigned and tentative species (Hassani-Mehraban et al., 2010). The species were devided into three clades reflecting the original of distribution, American, Eurasian and Asian (Pappu et al., 2009). Furthermore, based on the viral protein sequences, the TNRV isolates cluster within the Asian clade (Chiemsombat et al., 2010; Hassani-Mehraban et al., 2011; Seepiban et al., 2011). Also, TNRV was put in the Asian Tospovirus group together with Capsicum chlorosis virus (CaCV), Watermelon silver mottle virus (WSMoV), Groundnut bud necrosis virus (GBNV), Watermelon bud necrosis virus (WBNV), Calla lily chlorotic spot virus (CCSV), Tomato zonate spot virus (TZSV) and Melon yellow spot virus (MYSV). This disease can be transmitted by Thrips palmi and Ceratothripoides claratris. Thus, elimination of these two insects in the production area will assist in controlling the disease. However, it is very difficult to control these insects by either chemical or biological control methods. Therefore the use of resistant varieties will be a better method to control the disease. Resistance to tospoviruses in peppers has been reported. TSWV resistance was found in several C. chinense accessions, including 'PI 152225' and 'PI 159236'. The resistance was expressed as a hypersensitive response and controlled by the dominant gene Tsw. (Black et al., 1991; Boiteux \& De Avila, 1994; 
Moury et al., 1997). Unfortunately, the Tsw gene is not effective against other tospovirus species which are in the same Asian group as TNRV including Groundnut ringspot virus (GRSV), Tomato chlorotic spot virus (TCSV) (Boiteux \& De Avila, 1994), Impatiens necrotic spot virus (INSV) (Roggero et al., 1999) and CaCV (McMichael et al., 2002). Meanwhile, resistance to CaCV was found in C. chinense 'PI 290972', also giving a hypersensitive response and inherited as a single dominant gene (Persley et al., 2005). In the previous work, two related $C$. annuum accessions have been identified as medium resistant to TNRV (Puangmalai et al., in press). The source of resistance showed lower infection rates and reduced severity symptoms in both insect transmitted and mechanical inoculation experiments. Hence, both accessions were employed in this study in order to determine the number of genes controlling this source of resistance in C. anпuиm.

\section{Materials and Methods}

The experiment was conducted in the Pongyeng sub-district of Maerim where TNRV is a major problem in greenhouse production of bell peppers. The laboratory work was carried out at the plant pathology laboratory of Hortigenetics Research (S.E. Asia) Limited (HGR), located in Sansai district, Chiang Mai Province, Thailand.

Two C. annuum inbred lines from HGR, PY-6423 (R1) and PY-6424 (R2), were used as resistant parents (R). The bell pepper cultivar 'Early California Wonder' (ECW) was used as a susceptible parent (S). Crosses between resistant and susceptible parents were made in both directions. F1 progenies were then crossed back to both resistant and susceptible parents and self pollinated to make F2 progenies. Seeds of all generations and crosses were saved and then sown for further evaluation. The susceptible host, C. chinense 'PI 159236', was first sown in the greenhouse as a spreader for the virus, which is naturally occurring and transmitted to the plants through Thrips. The seeds of the parents, F1s, backcrosses and the F2 population were sown in 72 cells plastic sowing trays. Peatmoss was used as sowing medium. The seedlings were grown in an insect free nursery, in $7.5 \mathrm{~cm}$. diameter pots. Seedlings were transplanted into plastic growing containers $(0.30 \times 15 \mathrm{~m})$ with coconut substrate at 45 days after sowing in the TNRV infected greenhouse. A Complete Randomized Block Design with 2 replicates was used for this study. Each replication contained 12 plants, and at least 180 plants for the F2 populations.

At 60 days after planting, plants were scored visually for Disease Incidence (DI) and Disease Severity (DS). The DI was the percentage of infected plants. The DS score was adjusted from Boiteux et al. (1993) by using a 0-4 rating scale with $0=$ no disease symptom, $1=$ weak apical leaf distortion, $2=$ top distortion and weak mosaic in older leaves, $3=$ strong leaf distortion and very clear necrotic ring spot symptoms in older leaves and $4=$ severe stunting, top distortion and general necrotic ring spot. The Disease Index (DX) was calculated as the following formula:

$$
D X=\frac{(0 \times a)+(1 \times b)+(2 x c)+(3 x d)+(4 \times e)}{(\mathrm{a}+\mathrm{b}+\mathrm{c}+\mathrm{d}+\mathrm{e})} \times 100
$$

Where $a, b, c, d$, e were the number of plants examined which fell into the catergories, 0, 1, 2, 3, 4(Cooke., 2006).

The data of parents and F1 progenies were analyzed using Statistix 9.0. The segregating F2 and backcrosses were analyzed using the Chi-square method. The presence of the TNRV virus was assessed in the infected leaves, fruits and stems by using a Double Antibody Sandwich ELISA format (DAS-ELISA) protocol from Prime Diagnostics (Plant Research International, Dr. D. Peters). The presence of the tospovirus MYSV was assessed by Direct Antigen Coating ELISA (DAC), protocol from Plant Health Clinic, Department of Plant Pathology, Kasetsart University, Kamphaengsaen Campus, Nakhonpathom, Thailand. The samples were considered as positive when the optical density (OD) values were above the mean of the healthy control twice at $405 \mathrm{~nm}$.

\section{Results and Discussions}

The TNRV symptoms began to develop on the susceptible parent (ECW) 14 days after transplanting. The virus infection was confirmed by the Elisa tests which showed positive to TNRV but negative to MYSV. The final observation was done at 60 days during fruiting phase. The disease parameters, DI, DS and DX, at 60 days after transplanting are shown in Table 1. The susceptible parent, 'ECW' showed 100\% infection rate combined with a high disease severity, resulting in disease index of 90. On the contrary, the resistant parents, 'PY-6423' (R1) and 'PY-6424' (R2) showed intermediate infection rates, combined with low disease severity rating, resulting in disease indices of 14.1 and 4.9 , respectively. The four F1 progenies, $\mathrm{ECW} \times \mathrm{R} 1, \mathrm{R} 1 \times \mathrm{ECW}, \mathrm{ECW} \times \mathrm{R} 2$ and $\mathrm{R} 2 \times$ ECW showed that disease parameters (DI, DS and DX) weren't significantly different from the susceptible parent. But their disease incidence and disease severity were significantly different from the resistant parents. Thus the F1s were rated as susceptible, indicating that the resistance is partial and is inherited in a recessive way. Both segregating $\mathrm{F} 2$ populations and backcrosses, $\mathrm{BC}_{\mathrm{S}}, \mathrm{BC}_{\mathrm{R}}$, were further investigated for mode of inheritance. All 
plants with disease severity scale 0 were defined as resistant and those with severity scale 1 to 4 were defined as susceptible. The percentage of resistant and susceptible plants for the parents, crosses, backcrosses and F2 populations are shown in Figure 1. All plants of the susceptible parent were rated as susceptible. Both resistant parents R1 and R2 showed some plants that were rated as resistant and some that were rated as susceptible, which could be explained by assuming that the resistance is partial. On the other hand, the backcross between $(\mathrm{ECW} \times \mathrm{R} 1)$ $\times \mathrm{ECW}$ was highly susceptible whereas the backcross between $(\mathrm{ECW} \times \mathrm{R} 2) \times \mathrm{ECW}$ showed medium susceptibility only. The backcrosses to the resistant parents segregated nearly equal numbers of resistant and susceptible plants. The $\mathrm{BC}_{\mathrm{R} 1}$ and $\mathrm{F} 2$ the segregation ratios for susceptible versus resistant plants fit a 1:1 and a 3:1 ratio, respectively, confirming a single recessive Mendelian gene model (Table 2). However, the $\mathrm{BC}_{\mathrm{R} 2}$ did not significantly fit this model. Also, these results indicated that the resistance of PY-6423 (R1) and PY-6424(R2) to TNRV could be inherited as a single recessive gene for partial resistance. The segregation ratio in back crossed populations, $\mathrm{BC}_{\mathrm{S}}$ and $\mathrm{BC}_{\mathrm{R} 2}$ could not fit to model (Table 2), this might be due to small population size and the natural inoculation method. A partial resistance gene with the presence of minor modifying genes may explain these deviating segregating ratios in these two back cross populations (Table 2). Previous studies of the Tomato spotted wilt virus (TSWV) resistance gene in C. chinense showed similar results (Boiteux, 1995). This can also explain the occurrence of the susceptible plants in both resistant parents and in the back cross with the resistant parents, R2. The occurrence of resistant plants in the $\mathrm{BC}_{\mathrm{S}}$ can be explained by the same modifying genes or as being plants escaping the virus infection due to the natural inoculation method. Another study of TSWV inheritance resistance in C. chinense showed the segregation ratio of resistant versus susceptible in F2, F3 and reciprocal backcrosses fit a dominant monogenic inheritance for the three resistance sources except for both F2 populations. There are three hypotheses were explained segregation distortions in those F2 included heterogeneity or contamination of the inoculum, TSWV evolution after inoculation and genetic incongruence in the interspecific crosses (Moury et al., 1997). The results of inheritance of Tomato necrotic ring virus resistance in C. annuum should be a benefit to pepper breeding programs for introduction of partial resistance against TNRV in Thailand.

Table 1. The disease parameters, disease incidence (DI), disease severity (DS) and disease index (DI), of the parents, $\mathrm{F} 1 \mathrm{~s}$ and $\mathrm{BC} 1 \mathrm{~s}$ at 60 days after transplanting

\begin{tabular}{lccc}
\hline Parents and F1 progenies & Disease Incidence* (\%) & Disease severity* & Disease Index* \\
\hline ECW (S) & $100.0 \mathrm{a}$ & $3.6 \mathrm{a}$ & $90.0 \mathrm{a}$ \\
S x R1 & $100.0 \mathrm{a}$ & $3.3 \mathrm{a}$ & $82.8 \mathrm{a}$ \\
R1 x S & $94.5 \mathrm{a}$ & $2.9 \mathrm{a}$ & $77.8 \mathrm{a}$ \\
R2 x S & $80.0 \mathrm{ab}$ & $2.6 \mathrm{a}$ & $55.5 \mathrm{ab}$ \\
S x R2 & $78.6 \mathrm{ab}$ & $2.5 \mathrm{ab}$ & $51.9 \mathrm{ab}$ \\
R1 (PY-6423) & $50.0 \mathrm{bc}$ & $1.3 \mathrm{bc}$ & $14.1 \mathrm{~b}$ \\
R2 (PY-6424) & $25.0 \mathrm{c}$ & $0.8 \mathrm{c}$ & $4.9 \mathrm{~b}$ \\
\hline
\end{tabular}

* Mean values within column followed by the same letter are not significant different base on LSD Test $(\mathrm{P}=0.05)$.

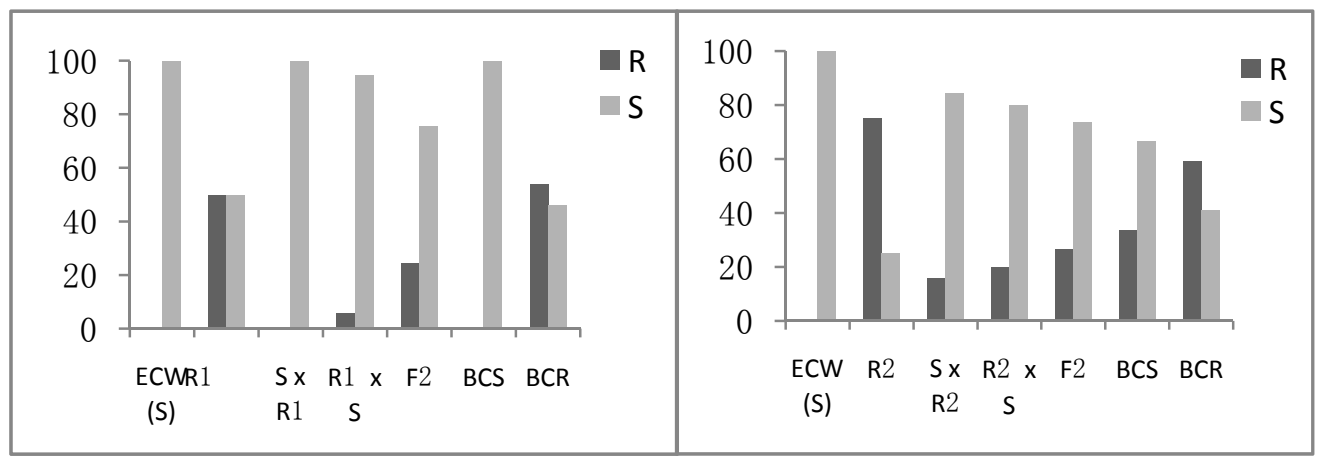

Figure 1. Number of resistant and susceptible plants based on the disease incidence (\%) in the parents, crosses, backcrosses and $\mathrm{F} 2$ populations 
Table 2. Segregation of resistant and susceptible plants in crosses derived from selfed of parental plants, F1 of resistant $\times$ susceptible, susceptible $\times$ resistant, F2 of susceptible $\times$ resistant and backcrosses

\begin{tabular}{lcccccccc}
\hline \multicolumn{7}{c}{ Observed } & Expected \\
\hline Populations & Total plants & $\mathrm{R}^{\mathrm{x}}$ & $\mathrm{S}^{\mathrm{y}}$ & $\mathrm{R}$ & $\mathrm{S}$ & Ratio $^{\mathrm{z}}(\mathrm{R}: \mathrm{S})$ & $\chi^{2}$ & $P$ value \\
\hline ECW (S) & 20 & 0 & 20 & & & - & - & - \\
$\mathrm{R} 1$ (PY-6423) & 22 & 11 & 11 & & - & - & - \\
F1 (S x R1) & 20 & 0 & 20 & & & - & - & - \\
F1 (R1 x S) & 18 & 1 & 17 & & & - & - & - \\
F2 (S x R1) & 180 & 44 & 136 & 45 & 135 & $1: 3$ & 0.030 & 0.863 \\
$\mathrm{BC}_{\mathrm{S}}$ & 18 & 0 & 18 & 0 & 18 & $0: 1$ & - & - \\
$\mathrm{BC}_{\mathrm{R} 1}$ & 26 & 14 & 12 & 13 & 13 & $1: 1$ & 0.154 & 0.695 \\
$\mathrm{R} 2$ (PY-6424) & 20 & 15 & 5 & & & - & - & - \\
F1 (S x R2) & 19 & 3 & 16 & & & - & - & - \\
F1 (R2 x S) & 20 & 4 & 16 & & & - & - & - \\
F2 (S x R2) & 193 & 51 & 142 & 48 & 145 & $1: 3$ & 0.250 & 0.648 \\
$\mathrm{BC}_{\mathrm{S}}$ & 24 & 8 & 16 & 0 & 24 & $0: 1$ & - & - \\
$\mathrm{BC}_{\mathrm{R} 2}$ & 22 & 13 & 9 & 11 & 11 & $1: 1$ & 0.727 & 0.394 \\
\hline
\end{tabular}

${ }^{\mathrm{X}}$ Disease severity scale 0 was defined as resistance.

${ }^{\mathrm{Y}}$ Disease severity scale 1 to 4 was defined as susceptible.

${ }^{\mathrm{Z}}$ Hypothesized segregation ratio of resistance (R) to susceptible (S) plants
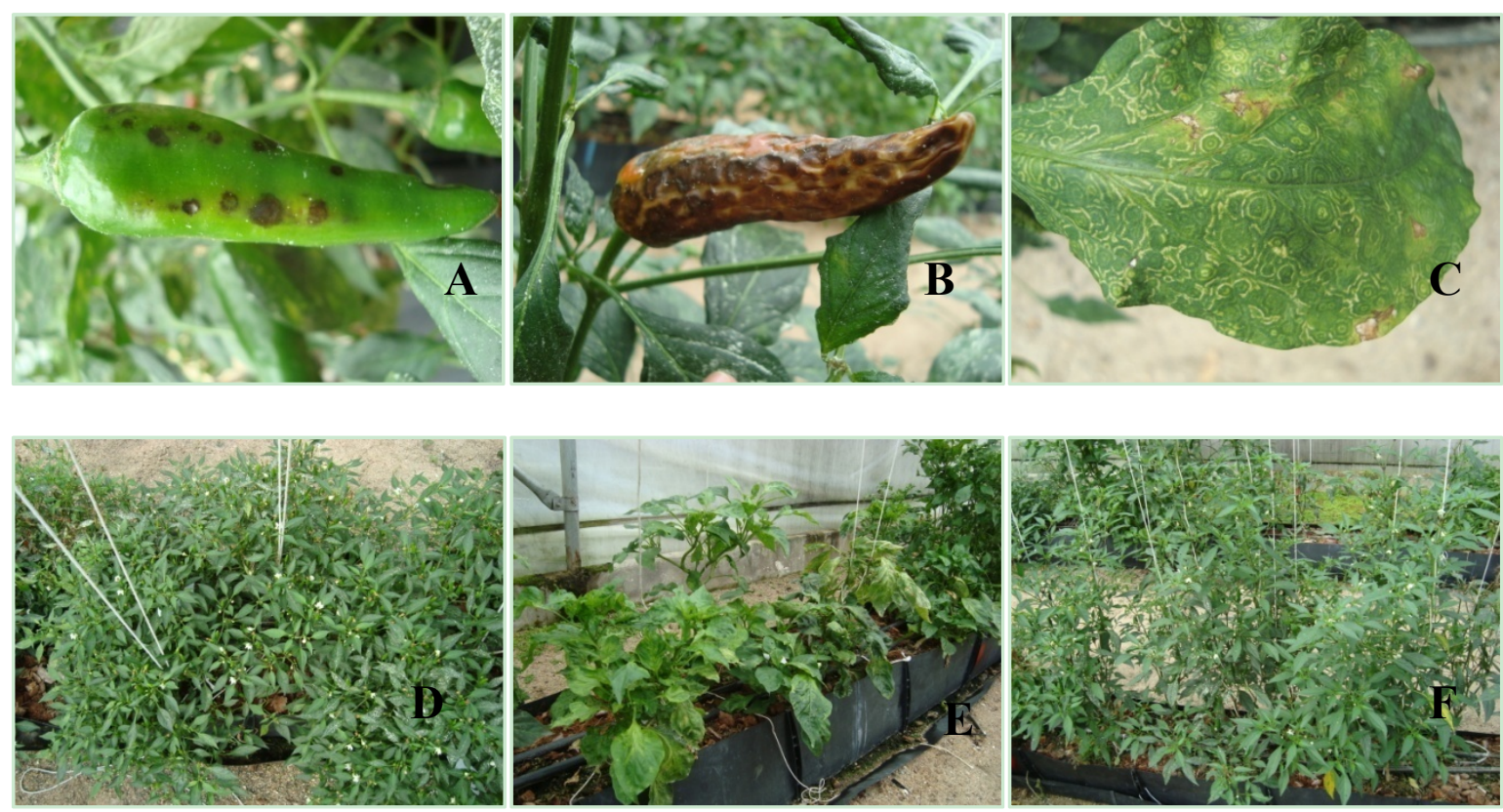

Figure 2. Symptoms on pepper plant naturally infected with TNRV. Necrotic ring on fruits (A, B). Yellow ring on a pepper leaf (C). Resistance parents PY-6423 (D), Susceptible parent ECW (E), Resistance parent PY-6424 (F).

\section{Acknowledgements}

The authors are grateful to HGR for providing of Capsicum germplasm, laboratory and greenhouse facilities.

Sincerely thanks extend to Ms. Sirirat Cheewachaiwit, Mrs. Jutharat Chuapong and Ms. Wassana Sittivate for their kind support in laboratory techniques. 


\section{References}

Black, L. L., Hobbs, H. A., \& Gatti, J. M. (1991). Tomato spotted wilt virus resistance in Capsicum chinense. PI 152225 and 159236. Plant Dis., 75, 863. http://dx.doi.org/10.1094/PD-75-0863A.

Boiteux, L. S. (1995). Allelic relationships between genes for resistance to tomato spotted wilt tospovirus in Capsicum chinense. Theor. Appl. Genet., 90, 146-149. http://dx.doi.org/10.1007/BF00221009

Boiteux, L. S., \& De Avila, A. C. (1994). Inheritance of a resistance specific to tomato spotted wilt in Capsicum chinense'PI 159236'. Euphytica, 75, 139-142. http://dx.doi.org/10.1007/BF00024541

Boiteux, L. S., Nagata, T., Dutra, W. P., \& Fonseca, M. E. N. (1993). Sources of resistance to tomato spotted wilt virus (TSWV) in cultivated and wild species of Capsicum. Euphytica, 67, 89-94. http://dx.doi.org/10.1007/BF00022729

Chiemsombat, P., Sharman, M., Srivilai, K., Campbell, P., Persley D., \& Attathom, S. (2010). A new tospovirus species infecting Solanum esculentum and Capsicum annuum in Thailand. Australasian Plant Disease Note, $5,75-78$.

Cooke, B. M., Gareth, J. D., \& Kaye, B. (2006). Disease assessment and yield loss. The epidermiology of plant disease (2 edn.) (pp. 43-80), Springer. Dordrecht, The Natherlands.

Hassani-Mehraban, A., Botermans, M., Verhoeven, K., Meekes, E., Saaijer, J., \& Peters, D. (2010). A distinct tospovirus causing necrotic streak on Alstroemeria sp. in Colombia. Archives of Virology, 155, 423-428. http://dx.doi.org/10.1007/s00705-010-0590-7

Hassani-Mehraban, A., Cheewachaiwit, S., Relevante, C., Kormelink, R., \& Peters, D. (2011). Tomato necrotic ring virus (TNRV), a recently described tospovirus species infecting tomato and pepper in Thailand. Eur. J. Plant Pathol., 130, 449-456. http://dx.doi.org/10.1007/s10658-011-9771-9

Latham, L. J., \& Jones, R. A. C. (1997). Occurrence of tomato spotted wilt tospovirus innative flora, weeds and horticultural crops. Aust. J. Agric. Res., 48, 359-369.

McMichael, L. A., Persley, D. M., \& Thomas, J. E. (2002). A new tospovirus serogroup IV species infecting capsicum and tomato in Queensland, Australia. Australian Plant Path., 31, 231-239. http://dx.doi.org/10.1071/AP02016

Moury, B., Palloix, A., Selassie-Gebre, K., \& Marchoux, G. (1997). Hypersensitive resistance to tomato spotted wilt virus in three Capsicum chinense accessions is controlled by a single gene and is overcome by virulent strains. Euphytica, 94, 45-52. http://dx.doi.org/10.1023/A:1002997522379

Mumford, R. A., Barker, I., \& Wood, K. R. (1996). The biology of the tospoviruses. The Annals of Applied Biology, 128, 159-183. http://dx.doi.org/10.1111/j.1744-7348.1996.tb07097.x

Pappu, H. R., Jones, R. A. C., \& Jain, R. K. (2009). Global status of tospovirus epidemics in diverse cropping systems: successes achieved and challenges ahead. Virus Research, 141, 219-236. http://dx.doi.org/10.1016/j.virusres.2009.01.009

Persley, D. M., Sharman, M., Mcgrath, D., \& Garland, S. (2005). Developing capsicum and tomato cultivar with resistance to Tospoviruses in Australia. In VIII International Symposium on Thysanoptera andTospoviruses, September 11-15, 2005, Asilomar, Pacific Grove, California. Journal of Insect Sciences, 7, 28. Retrieved from http://insectscience.org/7.28

Puangmalai, P., Potapohn, N., Akarapisarn, A., Cheewachaiwit, S., \& Insuan, N. (in press). Screening Capsicum Accessions for Tospovirus "Tomato Necrotic Ringspot Virus” Resistance. CMUJ of Nat. Sci.

Roggero, P., Dellavalle, G., Ciuffo, M., \& Pennazio, S. (1999). Effects of temperature on infection in Capsicum sp. and Nicotiana benthamiana by impatiens necrotic spot tospovirus. Eur. J. Plant Pathol., 105, $509-512$. http://dx.doi.org/10.1023/A:1008742516820

Seepiban, C., Gajanandana, O., Attathom, T., \& Attathom, S. (2011). Tomato ring spot virus, a new of tospovirus isolated in Thailand. Archives Virology, 156, 263-274. http://dx.doi.org/10.1007/s00705-010-0856-0

Vaira, A. M., Roggero, P., Luisoni, E., Masenga, V, Milne, R. G., \& Lisa, V. (1993). Characterization of two Tospoviruses in Italy: tomato spotted wilt and impatiens necrotic spot. Plant Pathology, 42, 530-542. http://dx.doi.org/10.1111/j.1365-3059.1993.tb01533.x 